\title{
Chapter 8 \\ Environmental Concerns of the Pulp and Paper Industry: Focusing on Household and Sanitary Paper Products
}

\section{Kun Qian}

\begin{abstract}
The category of household and sanitary products is the most important category in the paper industry, because it is related to people's daily lives all around the world. This category is seeing a rapid increase in consumption, while consumption in other categories, such as printing or writing paper, is presently declining. China is the largest manufacturer, as well as the largest consumer of household and sanitary paper. Nowadays, environmental consciousness and concerns are rising in China and have started to influence customers' behavior in selecting and using paper products. In the present study, surveys were conducted of the paper industry, the retail market for paper, and end consumers of paper. The relationship between new challenges of the paper industry and consumers' environmental concerns has been investigated and reported.
\end{abstract}

Keywords Customer behavior · Paper consumption · Environmental consciousness $\cdot$ Plantation $\cdot$ Environmental issue

\section{Introduction}

The pulp and paper industry is one of the industries that have resulted in serious environmental impacts all over the world and is facing increasing challenges in terms of environmental regulations (Young and Akhtar 1998). According to the classification of forest products, paper products (paper and paperboard) are mainly composed of four types (Food and Agriculture Organization of the United Nations 1982): newsprint, other printing and writing paper, household and sanitary paper, and wrapping and packaging paper. The newspaper is defined as an uncoated paper used for newspaper printings. Other printing and writing paper include paper used for other types of printings (e.g., books, magazines, photographs, or other

\footnotetext{
K. Qian $(\bowtie)$

The Institute of Decision Science for a Sustainable Society, Kyushu University, Fukuoka, Japan e-mail: qk@kyudai.jp
} 
commercial printings) and office use (e.g., copy paper, writing paper). Household and sanitary paper includes paper used in daily life, such as tissues, napkins, paper towels, and toilet paper. Wrapping and packaging paper includes those types of paper mainly used for packaging, such as liner board, craft paper, folding boxboard, and paperboard. The production, as well as the marketing of these four types of paper, is highly dependent on the economic and technological conditions in the global marketplace. Production of paper for newsprint sharply decreased after the 2008 financial crisis. The market for other print and writing paper is now threatened by the growth of digital information and the movement towards paperless offices. Alternatively, household and sanitary paper represents an irreplaceable use of paper, and consumption is still rapidly increasing, especially in some developing countries (Yano Research Institute 2016). The remarkable growth of e-commerce has also provided opportunities for the marketing of wrapping and packaging paper (Ministry of Economy, Trade and Industry of Japan 2016). In this study, household and sanitary paper (hereinafter referred to as "household paper") was selected as the target, because it is most dependent on the personal consumer, compared with other types of paper mainly used for industrial or business purposes, and it is still growing.

China is a big market for the pulp and paper industry, not only for paper production but also for its consumption. In 2009, China overtook the United States as the top producer, as well as the top consumer, of paper products in the world (China Paper Association 2018). In the total market for household paper, China achieved an average growth of 5.5\% from 2011 to 2014 and reached 12 billion USD in 2014 (Ministry of Economy, Trade and Industry of Japan 2016). However, the consumption of household paper per capita/year was only $4.7 \mathrm{~kg}$, somewhat lower than the consumption (by 1/3 to 1/5) in developed countries (Ministry of Economy, Trade and Industry of Japan 2016). With future economic growth in China, it is expected that consumption of household paper will also increase. A prospective analysis (RISI Analytics 2014) showed that from 2000 to 2012, China was responsible for one third of the total global growth of tissue consumption (10.5 million tons, 874,000 tons/year) and from 2012 to 2022 , China will be responsible for $41 \%$ of the expected growth of global tissue consumption (15 million tons). Tissue paper can be considered as a typical example of the whole household paper industry. The development of sanitary conditions and consciousness in China increases demand and consequently supply of household paper. Free toilet paper is increasingly available in public toilets utilizing advanced IoT technologies, which presents a big business opportunity for distributing free toilet paper (Fig. 8.1). On the other hand, environmental consciousness, especially awareness of specific environmental issues, is rising in the Chinese society, because of the noticeable deterioration of air quality in recent years, including the heavy smog in major Chinese cities such as Beijing and Shanghai (Zhao et al. 2016).

Considering the possible environmental impact caused by paper production, increased environmental consciousness may influence or change the behavior of customers in selecting and consuming household paper. In China, tissue and toilet paper products made from bamboo or straw fibers, instead of wood pulp, appeared in the market in 2010 (Ren et al. 2019). The unique selling proposition (USP) of those 


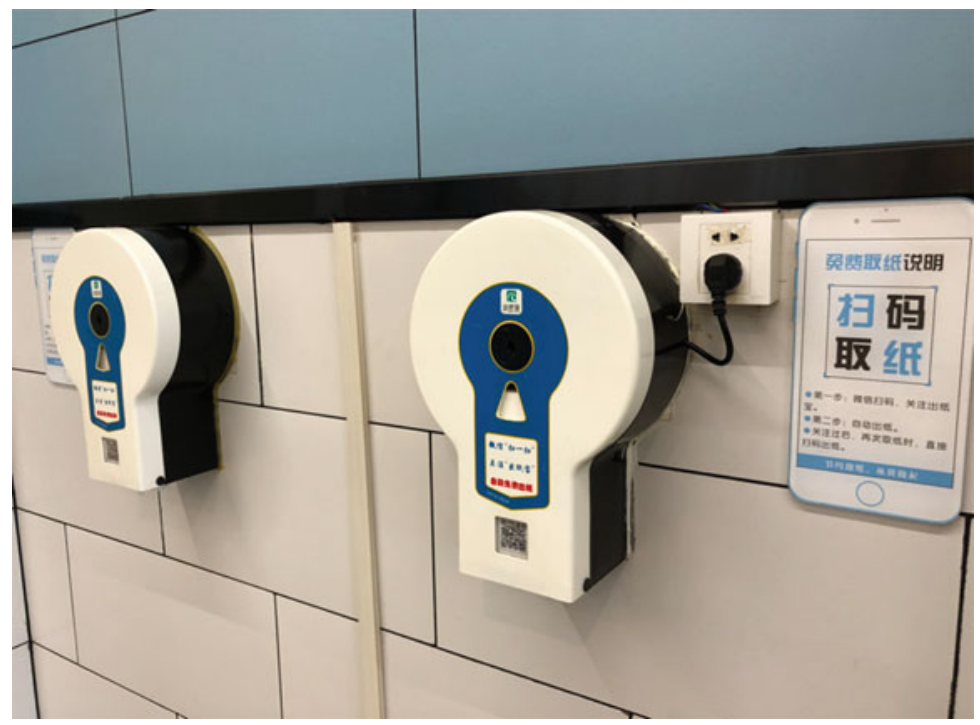

Fig. 8.1 Electronic toilet paper distributor in a public washroom in rest area of G2 BeijingShanghai Expressway. Use SNS applications and QR code to get free toilet paper

non-wood-based products is their reduced environmental impact from two aspects. First, most wood pulp was produced from the vast plantations in Southeast Asia, where almost all of the old-growth forests have been felled and converted to commercial plantations. This destruction has resulted in serious damage to local ecological systems, eliminating the natural biodiversity. Organisms that lived in the old-growth forests cannot survive in the environment of single species tree plantations. This is the most critical reason why people and environmental organizations oppose to commercial plantations. Bamboo- or straw-based paper products are not derived from wood pulp; thus, they are more environmentally friendly because they do not require the conversion of old-growth forests to plantations. Second, in northern China, wheat is a staple crop. Burning wheat straw in late autumn is considered to be an important contributor to air pollution, especially to the production of smog in winter (Qu et al. 2012). Producers of straw-based household paper appealed to the market by claiming that recycling straw to produce paper can reduce burning it and accordingly, decrease the possible air pollution resulting from straw burning. Both selling propositions are quite reasonable and have brought success and expansion to the market for these paper products made from alternative materials.

Changes to the concentration ratio $(\mathrm{CR})$ of household paper production corroborates the growth of the non-wood-based household paper market. Non-wood-based production is preferred by medium-sized manufacturers, because bamboo or straw materials can be procured domestically. The risk and cost of procurement are much lower than those associated with importing wood-based materials from Southeast Asia. Compared with the other three types of paper products, the CR of household 
paper production declined rapidly after 2010. Annual reports from the China Paper Association (2018) showed that the CR4 before 2010 was consistently above $47 \%$ and sharply dropped to $27.7 \%$ in 2015 . Analysis of a report released by Guolian Securities (2019) showed that the top four manufacturers of household paper in China are Gold HongYe Paper (market share 9.7\%), Hengan International (8.5\%), Vinda International (8.2\%), and C\&S Paper (4.2\%). The CR4 of these companies was $28.2 \%$ in 2017 . The data suggest that a great number of new manufacturers joined the household paper market in the first 5 years of the 2010 decade.

The rise of non-wood-based household paper definitely threatens the traditional manufacturers using wood pulp. In 2017, the total consumption of pulp in China was 101 million tons. Sixty-three percent of the pulp was recycled (21\% imported, $42 \%$ domestic), $31 \%$ was wood pulp (21\% imported, $10 \%$ domestic), and $6 \%$ was non-wood pulp (all domestic, United Credit Ratings 2018). Six percent is not a significant percentage, but most of the non-wood pulp was used to produce household paper, and household paper production was just $8.6 \%$ of all paper production in 2017. This means, as a material for household paper production, non-wood pulp is playing an important role in China. Not only the end manufacturers but also the whole supply chain of imported wood pulp (21 million tons in $2017,68 \%$ of the wood pulp consumption) will be influenced. Since 2009 , the international trade price of wood pulp has continued to rise, putting pressure on paper manufacturers to improve cost control and supply chain management (Sinolink Securities 2018). Non-wood pulps provide an opportune alternative to these companies. China imports wood pulp mainly from Canada (23\%), Brazil (19\%), Indonesia (12\%), Chile (10\%), and the United States (9\%). The biggest household paper company, Gold HongYe Paper, is a member of the Asia Pulp \& Paper Group (APP), based in Indonesia. Even though Indonesia is not the largest supplier of wood pulp for China, imported wood pulp from Indonesia is more likely to be used for household paper production. This means the rise of non-wood-based household paper production in China will negatively impact the plantation industry in Indonesia.

As mentioned above, commercial plantations in Southeast Asia have been criticized by nongovernmental organizations (NGOs), such as the World Wildlife Fund (WWF), because of the plantations' lack of environmental protections and prevalence of social conflicts (Szulecka et al. 2016). Forest fires and the attendant haze have caused more environmental issues (Tacconi 2016). As a result, rising environmental concerns of consumers in China are changing their selection of household paper products. The purpose of this study is to clarify the changing situation, as well as to identify the trends affecting the household paper market in China.

\section{Methods}

In this study, I conducted surveys of three different aspects of the household and sanitary paper industry: manufacturers, markets, and consumers. APP was selected to represent manufacturers, because it is the largest household paper vendor in China 
and has the strongest relationship with the Southeast Asian plantations. As to the surveys of markets and consumers, data were obtained from several economically developed regions in China, where the consumption of household paper is greater than in other regions. In total, 16 surveys ( 3 to Indonesia and 13 to China) were conducted from 2015 to 2019.

There are a variety of products in the category of household and sanitary paper, such as box tissues, pocket tissues, toilet paper, table napkins, kitchen paper, wet tissues, sanitary napkins, disposable diapers, etc. However, bamboo or straw pulp is used mostly to produce box tissues, pocket tissues, and toilet paper. Thus, I selected these three types of paper products to be the target of the surveys. Surveys 1 and 3 were conducted by using the method of an unstructured interview.

\subsection{Survey 1: Visit and Interview APP Paper Mills}

As the first step of the research, the manufacture of household paper in China was explored at each point of its supply chain. I visited an APP plantation, an R\&D center, and one of its largest pulp and paper mills (Perawang Mill in Sumatra, Indonesia), from 2015 to early 2016, as pilot surveys.

The main surveys were conducted in 2016 and 2017, by visiting six APP member companies, as well as their mills. This included the headquarters of Gold HongYe Paper (GHY), the largest household paper manufacturer in China, located in Jiangsu, Shandong, and Guangdong Provinces of China. As part of the surveys, I interviewed 15 staff members in administrative positions at different mills and departments. Details of the interview sites and informants are listed in Table 8.1.

\subsection{Survey 2: Market Survey of Household Paper Products}

To grasp the market situation of household paper products, especially the non-woodbased ones, market surveys were conducted from late 2016 to 2017. Twenty-five end retail markets in seven cities (Changzhou in Jiangsu Province, Shenzhen and Qingyuan in Guangdong Province, Langfang in Hebei Province, Qingdao in Shandong Province, Shanghai, Beijing) were included. Most urban citizens in China tend to buy household paper products in the major supermarkets in their cities; thus, this survey focused on the major supermarkets in the seven cities. To investigate the relationship between market share of non-wood-based, or the so-called eco-friendly paper products, and the amount of air pollution in an area, the survey sites were selected from both northern and southern parts of China. Southern China's staple crop is rice, so burning straw is not a contributor to air pollution there. The amount of wood-based box tissues, pocket tissues, and toilet paper products, as well as that of non-wood-based products, was sampled in each end market. Details of the end markets surveyed are shown in Table 8.2, with the sampled data. 
Table 8.1 Detailed information on interview sites and informants for survey 1

\begin{tabular}{|c|c|c|c|}
\hline Time & $\begin{array}{l}\text { Place (city, } \\
\text { province) }\end{array}$ & Company and mill & Informant (department) \\
\hline \multirow{4}{*}{$\begin{array}{l}\text { November- } \\
\text { December } 2016\end{array}$} & \multirow{4}{*}{$\begin{array}{l}\text { Suzhou, } \\
\text { Jiangsu }\end{array}$} & \multirow{4}{*}{$\begin{array}{l}\text { Gold HongYe (GHY) Paper } \\
\text { headquarter mill }\end{array}$} & IF1, publicity \\
\hline & & & $\begin{array}{l}\text { IF2, finished good expert } \\
\text { (region representative) }\end{array}$ \\
\hline & & & $\begin{array}{l}\text { IF3, finished good expert } \\
\text { (Asia-Pacific department) }\end{array}$ \\
\hline & & & IF4, production line \\
\hline \multirow{3}{*}{$\begin{array}{l}\text { November- } \\
\text { December } 2016\end{array}$} & \multirow{3}{*}{\begin{tabular}{|l} 
Suzhou, \\
Jiangsu
\end{tabular}} & \multirow{3}{*}{$\begin{array}{l}\text { Gold Huasheng (GHS) } \\
\text { Paper headquarter mill }\end{array}$} & IF5, research and development \\
\hline & & & $\begin{array}{l}\text { IF6, environment and } \\
\text { sustainability }\end{array}$ \\
\hline & & & IF7, marketing and sales \\
\hline \multirow{3}{*}{$\begin{array}{l}\text { November- } \\
\text { December } 2016\end{array}$} & \multirow{3}{*}{$\begin{array}{l}\text { Zhenjiang, } \\
\text { Jiangsu }\end{array}$} & \multirow{3}{*}{$\begin{array}{l}\text { Gold East Paper } \\
\text { headquarter mill }\end{array}$} & IF8, publicity \\
\hline & & & IF9, global procurement \\
\hline & & & $\begin{array}{l}\text { IF10, environment } \\
\text { management }\end{array}$ \\
\hline \multirow[t]{3}{*}{ February 2017} & \multirow[t]{3}{*}{$\begin{array}{l}\text { Qingyuan, } \\
\text { Guangdong }\end{array}$} & \multirow[t]{3}{*}{$\begin{array}{l}\text { Branch mills of GHY and } \\
\text { GHS }\end{array}$} & \begin{tabular}{|l|} 
IF11, supply chain \\
management
\end{tabular} \\
\hline & & & IF12, global procurement \\
\hline & & & IF13, production line \\
\hline \multirow[t]{2}{*}{ March 2017} & \multirow{2}{*}{$\begin{array}{l}\text { Qingdao, } \\
\text { Shandong }\end{array}$} & \multirow{2}{*}{$\begin{array}{l}\text { Branch mills of GHY and } \\
\text { GHS }\end{array}$} & IF14, publicity \\
\hline & & & $\begin{array}{l}\text { IF15, supply chain } \\
\text { management }\end{array}$ \\
\hline
\end{tabular}

\subsection{Survey 3: Interview with End Consumers}

Finally, in 2018 and 2019, I interviewed university students as end consumers from six universities in Jiangsu, Shandong, Beijing, and Shanghai. Most university students in China live in dormitories on the campus. They are ideal customers who mainly consume box tissues, pocket tissues, and toilet paper but rarely use other types of household paper products. Also, university students are more concerned about the environment and sustainability and have higher than average social consciousness. They are also more sensitive to new technologies and products in the market.

Thirty-one students (17 females and 14 males; mean age $=21.3$ years; $S D=$ 1.3 years) were interviewed for the survey. All of them lived in the dormitories provided by their universities. They are born in 16 provinces around China. Expedited ethical approval for this survey was obtained from the Ethics Committee for Psychological Studies at the Institute of Decision Science for a Sustainable Society, Kyushu University (No. 2018/1-4). The interview method used in this study were conducted in accordance with the relevant guidelines of the ethics committee. 


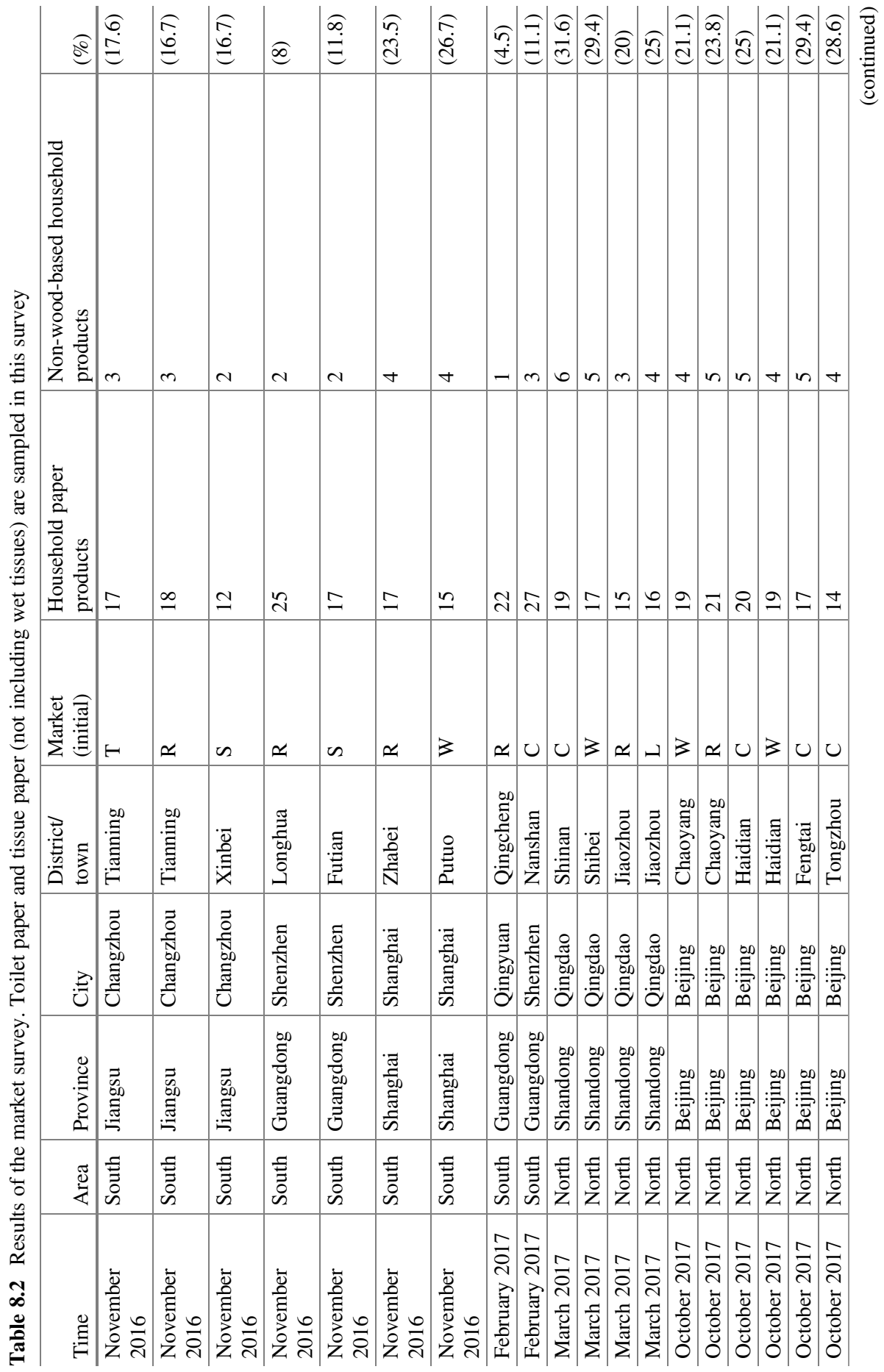




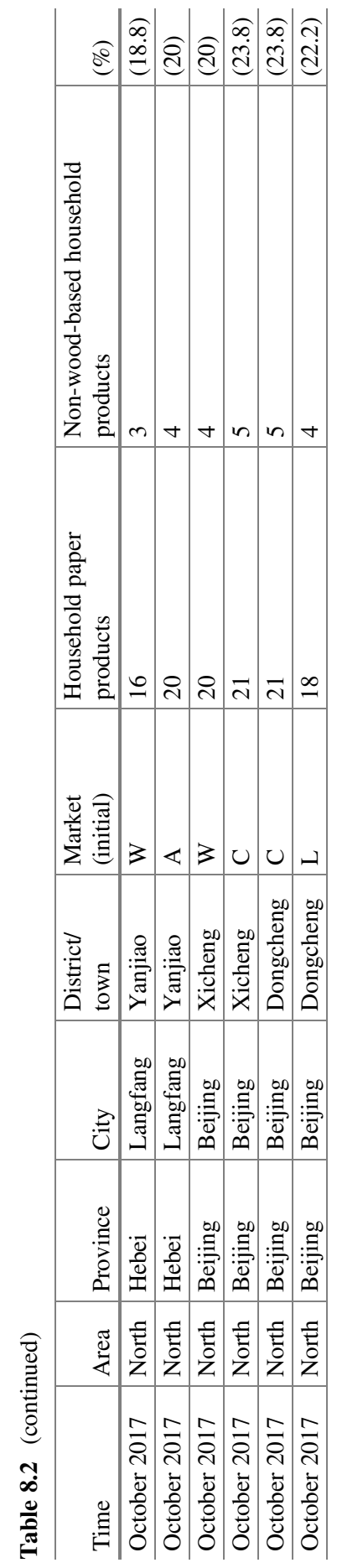




\section{Results}

\subsection{Challenges for Major Paper Manufacturers in China}

From the interviews of APP staff members in various positions and departments, some of the pressures and challenges for APP, as well as all the major paper manufacturers that are its members, were revealed.

The first pressure is from the business itself. Different from other major paper producing or consuming countries like the United States, Indonesia, Canada, or Brazil, the paper industry of China is much more reliant on the import of materials. China is the largest importer of wood pulp in the world. In 2015, China imported 16.5 million tons of pulp, more than the total of the second to the fifth largest importing countries (the United States, Germany, Italy, and South Korea). High reliance on material imports brings more cost, as well as risk, to the Chinese paper industry. Comparing two major subsidiary companies of APP, Perawang Mill in Indonesia is surrounded by thousands of hectares of plantation, which means that the cost of material distribution has never been a problem. However, GHY Mill in China must pay for the high cost of ocean transportation to get the same materials and has to face the rapid change of prices in the international pulp trade. This issue leads to a difficult situation in China, i.e., that the cost of raw materials is extremely high (approximately $65-80 \%$ of the total cost in paper manufacturing). Mass production has been considered the best way to mitigate high costs; however, the $\mathrm{CR}$ of the major manufacturers is becoming lower and lower in the current decade. Increasingly, mid-sized paper mills, including those who use bamboo or straw fibers instead of wood pulp to control cost, are appearing and becoming part of the household paper market. This directly influences and restrains the production of major manufacturers. In 2017, GHY operated at only $67.4 \%$ of capacity. Excess capacity gradually becomes a serious issue for major household paper manufacturers.

The second pressure is from the environmental policies in China, which are getting increasingly stringent during the current decade. In 2017 alone, five regulatory schemes on environmental conservation and emission control were revised or newly released to regulate the paper industry. To comply with the new policies, manufacturers have to change some of their suppliers, update their equipment, adjust their production processes, or even selectively shut down some old production lines, and all of these actions result in additional costs. From the beginning of 2010, the Chinese government has taken serious and drastic measures to improve the environmental situation in China. As one of the industries most highly impacting the environment and sustainability, paper companies are always the first target. Even though this additional cost is a big concern for GHY, all informants declared that concern for the environment and sustainability is 
their responsibility. They support the company's huge investment to improve and make their production facilities more eco-friendly and the related actions to comply with regulatory requirements. That is why GHY and the other APP member mills can run stably in the strictest areas of environmental monitoring in China, and why WWF China has not criticized APP China as seriously as companies in Indonesia.

Informants also mentioned the regional differences in the threats to APP's businesses, due to economic status and customer behaviors. Innovative, eco-friendly products, such as bamboo- or straw-based paper, are much more appealing in a region where air pollution is more serious. This was explored in more detail in the second survey.

\subsection{Difference in Market Penetration of Eco-friendly Household Paper Products in North and South China}

The results of the market survey are shown in Table 8.2. The number of household paper products, as well as that of non-wood-based products, was determined in each supermarket included in the survey. The percentage of non-wood-based products was calculated. In South China, the average percentage across nine markets was $15.18 \%$. However, in North China, the average percentage across 16 markets was $23.98 \%$. A two-tailed t-test showed that the percentage of non-wood-based products was significantly higher in North China markets than in South markets $(t(23)=$ $-4.00, p<.001$, Cohen's $d=-1.67)$. These results support the opinion of mill workers during survey 1 , that non-wood-based products are more popular in North China.

Non-wood-based products are normally more expensive, but less compatible than wood-based ones (Fig. 8.2). Buying non-wood-based products means paying more money to get products that will be used every day, but may not be comfortable to use. It seems difficult to understand this behavior, because consumers normally prefer better and cheaper products. One possible reason that customers in North China welcome and are willing to pay more for the so-called eco-friendly products is that they suffer more from air pollution than southern people. In winter, people in many northern cities of China must endure heavy smog resulting from air pollution. The selling proposition of non-wood-based products is consistent with the actual experience of consumers.

Non-wood-based products in the southern market are mainly made from bamboo, because as raw material, straw cannot be steadily supplied to South China. However, even though bamboo paper is irrelevant to reducing air pollution, it is considered to be an eco-friendly product and has won big support in the market. It implies that traditional pulp and paper manufacturing based on plantation trees is considered to 


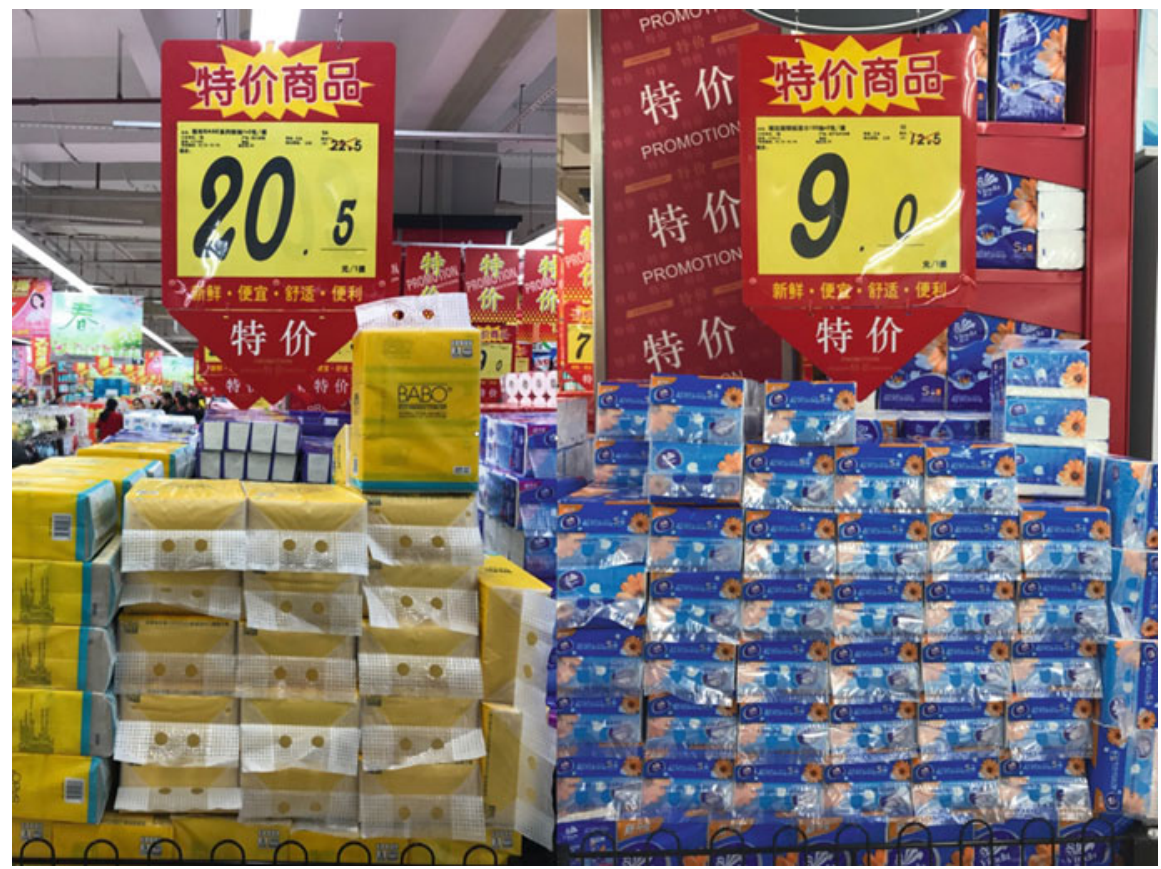

Fig. 8.2 Non-wood-based tissues (left) and wood-based tissues (right) on sale in a supermarket in Qingyuan, Guangdong Province (Feb. 2017). Non-wood products were much more expensive

be a less eco-friendly industry and that any innovation to reduce the environmental impact of this industry is welcomed by the end consumers.

\subsection{University Students Value Environment More When Selecting Household Paper Products}

All student interviewees indicated that they buy toilet paper and tissue paper in their daily lives. When asked to select factors influencing their purchasing decisions for household paper, $32.2 \%$ of them said they consider price as the highest priority, possibly because as students, their disposable income is limited. Quality was named as a priority by $25.8 \%$, while $19.4 \%$ selected comfort, and $16.1 \%$ selected environmental concerns as the highest influence on their purchase. Obviously, university students do not consider environmental concern as their highest priority when they buy household paper, but environmental concern is the only factor that was included in the top three by all students.

In Beijing and Shandong, 13 students out of 16 reported that they have tried tissues or toilet paper made from straw, due to a consideration for reducing air 
pollution. Eight of them kept using those products, even though all of them admit that straw paper is expensive and not as comfortable as normal paper. Straw products could hardly be found in Jiangsu and Shanghai, but bamboo products had more share there than in the northern regions. Ten in fifteen students told that they had consumed bamboo products, and six were still using them. Selecting bamboo products was also based on their consciousness of the environment. All students had a definite opinion that paper production brings serious impacts to the environment, through energy consumption, water consumption, gas and water emissions, and deforestation.

All students complained about smog pollution, but most of them admitted that air pollution has been improved year by year, especially in Beijing. They know that smog is the result of a variety of factors and that straw burning is just one of them, and not the most critical. Yet, they still prefer to purchase eco-friendly paper products that are affordable. This behavior implies their deep consciousness and concerns for the environment and sustainability.

\section{Discussion}

The present research focused on the marketing and production of household paper products in China; revealed the situation, trends, and challenges in the household paper industry in China; and investigated how the consciousness and concerns of end consumers influence their behavior for selecting and using paper products.

My awareness of issues addressed in this research actually began with my first visit to APP's plantation in Sumatra. After inspecting the boundless plantation, I was told about the environmental issues, social issues, difficult business situations, and the criticisms from NGOs and the academic world. However, as the global $\mathrm{CO}_{2}$ emission issue is being addressed in China, it is clear that the responsibility lies not only with the countries that produce $\mathrm{CO}_{2}$ but also with the countries that consume the products from those $\mathrm{CO}_{2}$-emitting processes. As to the issue of plantations in Indonesia, a large quantity of the wood pulp is exported to China and other countries. In China, the market for household paper produced by using pulp imported from Indonesia is threatened by the change of consumers' environmental concerns. This change is due in large part to the prevalence of air pollution and the desire to improve air quality. As shown in Fig. 8.3, the issues occurring on Indonesian plantations are indirectly, but absolutely related to the economic restructuring taking place in China. To solve the plantation issues in Indonesia, co-design and co-production among multiple stakeholders in Indonesia, as well as in China, are essential.

Surveys and inspections of administrative offices, plantations, and mills created a clear image of the supply chain in the paper industry. Viewing the process in four steps, plantation (produce wood) $\rightarrow$ pulp mills (turn wood to pulp) $\rightarrow$ paper mills (turn pulp to paper) $\rightarrow$ market (sale), I note that earlier stages are reliant on actions in developing countries, while developed countries concentrate on the later stages. Using APP as an example, its products are very popular in the Japanese market, but 


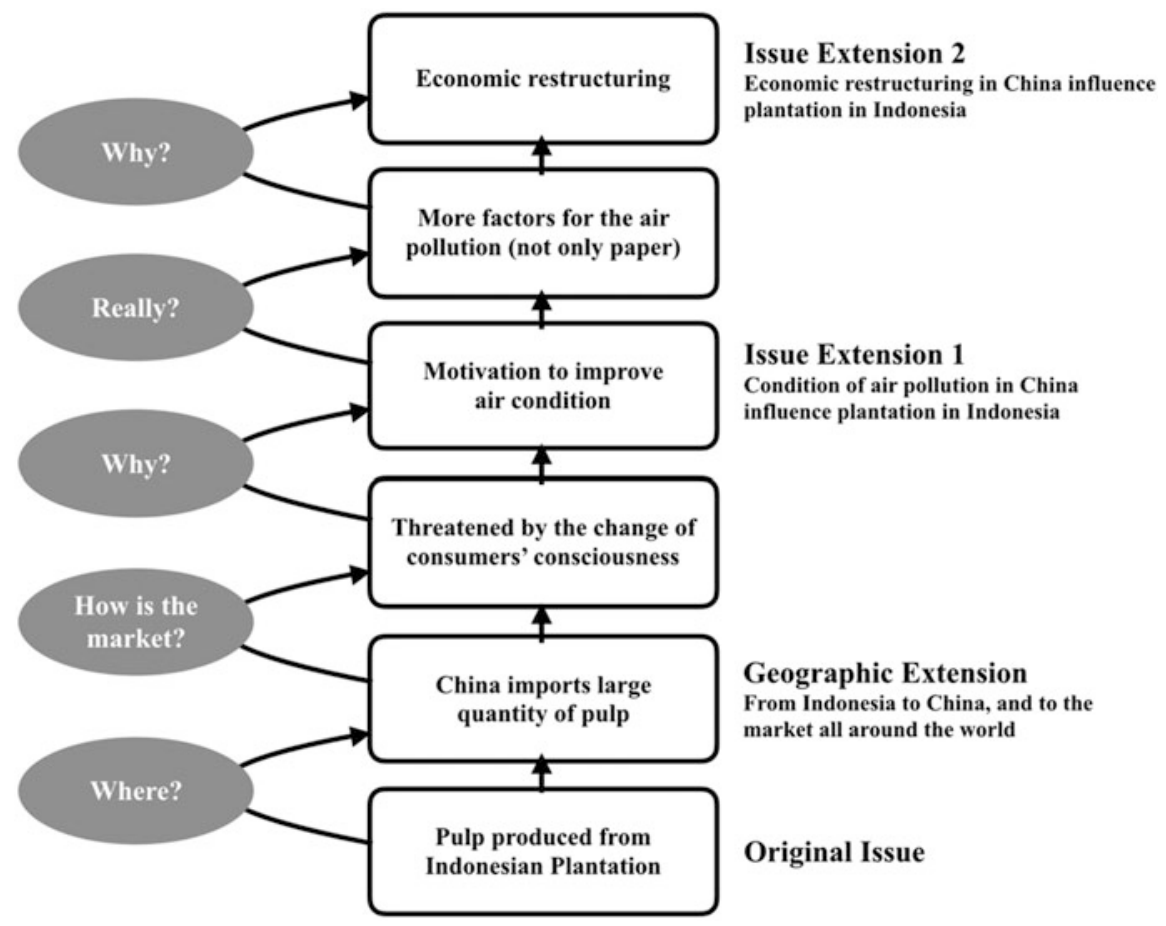

Fig. 8.3 Issue chain of the environmental sustainability of the household paper industry. Issues occurred in Indonesian plantations indirectly but finally related to the economic restructuring in China

there are no production facilities in Japan. This is a good example of the international division of labor and resources, which makes mass industrial production effective and efficient. However, it also explains how a global company like APP must face different stakeholders, difficulties, and issues in different regions and markets. In this case, co-design and co-production with all stakeholders become much more challenging.

The function of NGOs and nonprofit organizations (NPOs) should be emphasized here. NGOs and NPOs play an important role in monitoring the environmental impacts of paper manufacturers and in certifying the environmental performance of paper companies that comply with published standards such as those put forth by the Forest Stewardship Council (FSC), the Programme for the Endorsement of Forest Certification (PEFC), or the Sustainable Forestry Initiative (SFI). The positions of these organizations should be as impartial as possible, to be effective standard setters. However, the current trend is for certifications from organizations such as WWF or FSC to be used as marketing tools by paper companies, especially in Japan. During EcoPro 2017, the largest annual international exhibition on environment and energy in Japan, I witnessed that the largest retail company in Japan had 
placed FSC certifications on their private label household paper products. This could mislead consumers, who may think that all of the company's products are FSC-certified. However, one month before EcoPro 2017, I also witnessed that their best-selling private lable tissue products were produced in APP China, which have not been certified by FSC. The relationship between NGOs and vendors should be evaluated to assure NGOs play their roles in a neutral and fair manner.

Lastly, increasing environmental concerns related to the production of household paper products are also implicated in the innovation or revolution of the overall paper industry. Compared to printing and office paper usage, the usage of household paper products will continue to increase for some decades. However, the usage of paper, in general, is on the decline. Traditional paper production, with its huge environmental costs, will be changed in the future. Especially for the paper enterprises in Asia, innovation and sustainability will be the most important topics to be addressed.

Acknowledgments This work was supported by a grant JPMJRX16F1 from the Research Institute of Science and Technology for the Society (RISTEX) of the Japan Science and Technology Agency (JST), as part of the Future Earth programs.

\section{References}

China Paper Association (2018) Annual report of China paper industry 2018

Food and Agriculture Organization of the United Nations (1982) Classification and definitions of forest products. FAO Forest Pap 32:40-41

Guolian Securities (2019) Analysis report of C\&S Paper Co Ltd

Ministry of Economy, Trade and Industry of Japan (2016) Report on Overseas Survey on the Industry of Sanitary Paper. pp 2-3

Qu C, Li B, Wu H, Giesy JP (2012) Controlling air pollution from straw burning in China calls for efficient recycling. Environ Sci Technol 46(15): 7934-7936

Ren J, Yu P, Xu X (2019) Straw utilization in China—status and recommendations. Sustainability 11:1762. https://doi.org/10.3390/su11061762

RISI Analytics (2014) A look at global tissue markets

Sinolink Securities (2018) Analysis report of household paper industry

Szulecka J, Obidzinski K, Dermawan A (2016) Corporate-society engagement in plantation forestry in Indonesia: evolving approaches and their implications. Forest Policy Econ 62:19-29

Tacconi L (2016) Preventing fires and haze in Southeast Asia. Nat Clim Change 6(7):640

United Credit Ratings Co. Ltd. (2018) Research report of China paper industry 2018

Yano Research Institute Ltd. (2016) Overseas research report on sanitary paper industry

Young R, Akhtar M (1998) Environmentally friendly technologies for the pulp and paper industry. Wiley, New York

Zhao S, Yu Y, Yin D, He J, Liu N, Qu J, Xiao J (2016) Annual and diurnal variations of gaseous and particulate pollutants in 31 provincial capital cities based on in situ air quality monitoring data from China National Environmental Monitoring Center. Environ Int 86:92-106 
Open Access This chapter is licensed under the terms of the Creative Commons Attribution 4.0 International License (http://creativecommons.org/licenses/by/4.0/), which permits use, sharing, adaptation, distribution and reproduction in any medium or format, as long as you give appropriate credit to the original author(s) and the source, provide a link to the Creative Commons license and indicate if changes were made.

The images or other third party material in this chapter are included in the chapter's Creative Commons license, unless indicated otherwise in a credit line to the material. If material is not included in the chapter's Creative Commons license and your intended use is not permitted by statutory regulation or exceeds the permitted use, you will need to obtain permission directly from the copyright holder. 